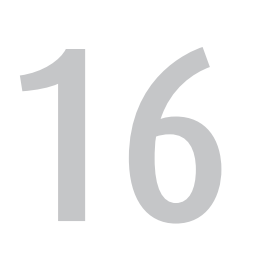

\title{
Holocene vegetation change at treeline, Cropp Valley, Southern Alps, New Zealand
}

\author{
Matt S. McGlone \\ Landcare Research, Lincoln, New Zealand \\ mcglonem@landcareresearch.co.nz
}

\section{Les Basher}

Landcare Research, Nelson, New Zealand

\section{Introduction}

New Zealand treelines have been well studied over the past few decades. Peter Wardle carried out extensive observational and experimental studies of their ecology and suggested that the length and warmth of summer was critical in permitting alpine trees to make sufficient growth to survive winter (Wardle 1985a). He also showed that New Zealand treelines were low when compared with global treelines, in particular with those of southern South America, and that exotic Pinus contorta could grow up to $300 \mathrm{~m}$ above the indigenous treeline (Wardle 1985b, 2008). A later global study demonstrated that warmth of the growing season was the one universal factor controlling position of treeline (Körner and Paulsen 2004). Both Wardle (2008) and Körner and Paulsen (2004) suggested New Zealand alpine trees were incapable of persisting under the cool growing season temperatures typical of treeline sites in most other regions, a possible result of having insufficient time to evolve cool-climate adaptations.

The 20th century trend towards warmer temperatures has intensified interest in treelines, as, being temperature-sensitive, they should be responding to the ca. $1^{\circ} \mathrm{C}$ increase in mean annual temperatures since $1900 \mathrm{AD}$. New Zealand investigations have shown there has been little or no response (Wardle and Coleman 1992; Cullen et al. 2001), and a global synthesis (Harsch et al. 2009) indicated that, while many treelines were rising, almost as many were static.

Despite this interest, and the large extent of alpine terrain in New Zealand, relatively little palaeoecological work has been reported from sites above, at, or close to treeline. In contrast, Tasmania and southeastern Australia, in part because of Peter Kershaw's long-standing interest, have many intensively investigated subalpine to alpine sites and a wealth of information on 
their treeline history (e.g. Kershaw and Strickland 1988; McKenzie 1997, 2002; Kershaw et al. 2007).

Central western districts of the Southern Alps are of great interest from both ecological and biogeographic perspectives because they lie in the western 'beech' gap of the Southern Alps. This extensive region lacks Nothofagus, arguably because of its exclusion by ice during the Last Glacial Maximum (McGlone et al. 1996). As the vast majority of New Zealand treelines are of Nothofagus, the history of a non-Nothofagus treeline gives a valuable additional perspective. The work presented here consists of several pollen profiles from a west-central Southern Alps alpine site. A summary diagram from this site with a line of accompanying text was included in a review of New Zealand postglacial vegetation history (McGlone 1988). Given the inherent interest in treelines, the renewed importance of understanding them in the context of climate changes, and the paucity of palaeoecological sites at treeline in New Zealand, it was thought appropriate to fully document the site and discuss it in the context of Australasian alpine results.

\section{Environmental setting}

\section{Topology and geology}

The Cropp River drains an alpine-montane basin of some $28.5 \mathrm{~km}^{2}$, centred on $43^{\circ} 05^{\prime} \mathrm{S}$, $170^{\circ} 58^{\prime} \mathrm{E}$, on the western flanks of the central Southern Alps. This section of the Southern Alps has extremely high annual precipitation and high erosion rates. The basin is $8 \mathrm{~km}$ by $3.5 \mathrm{~km}$ and has a predominantly east-west orientation, ranging in elevation from $2140 \mathrm{~m}$ (Mount Beaumont) to $240 \mathrm{~m}$ at the confluence of the Cropp and Whitcombe Rivers (Figure 1).

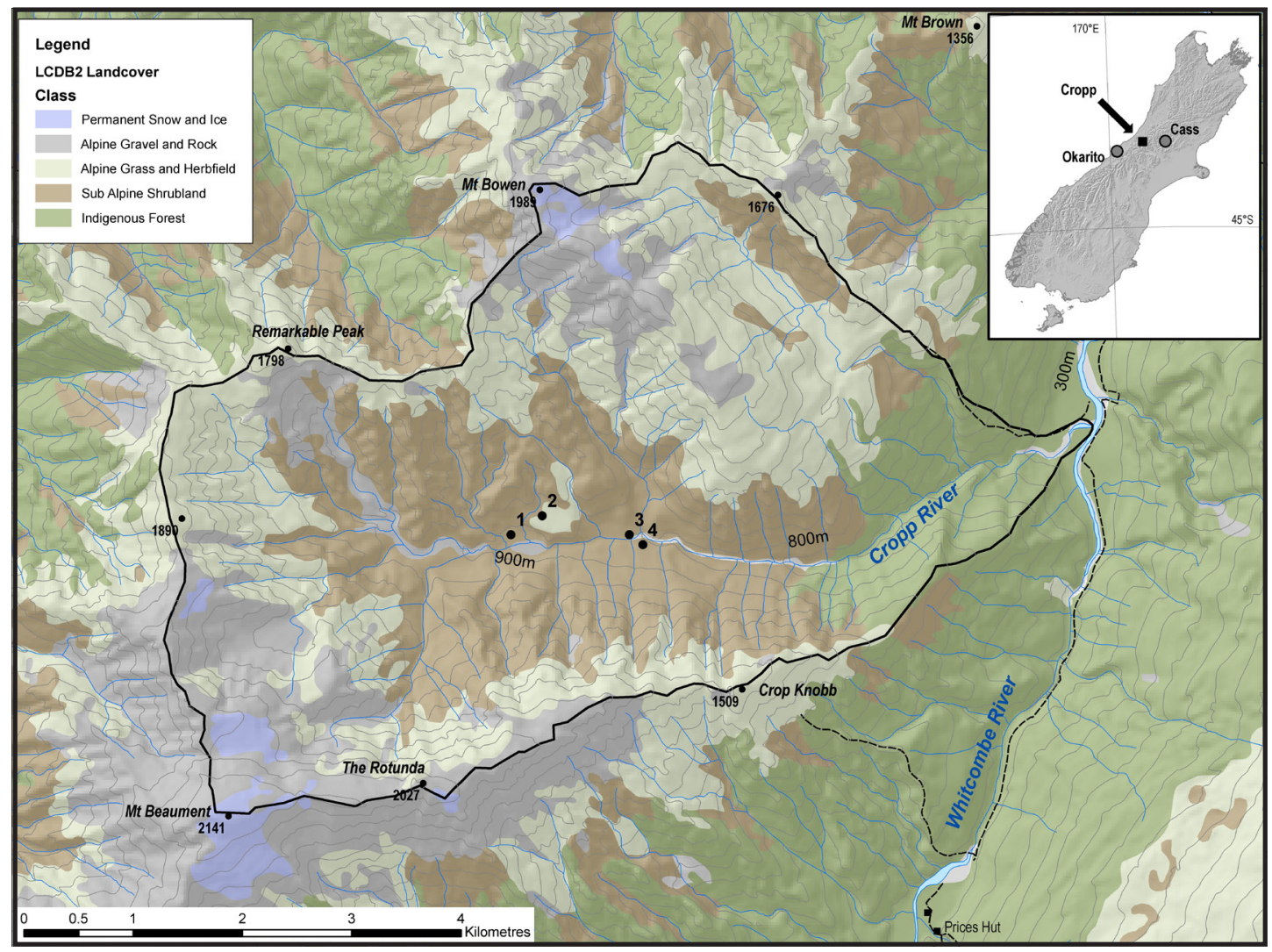

Figure 1. Location map, Cropp Valley, west-central Southern Alps, New Zealand. Inset: South Island, New Zealand. 
The basin is composed of high-grade metamorphic rocks of green schist to amphibolite facies. The rocks are highly fissile and commonly intensely fractured. As it lies 5-8 km southeast of the Alpine Fault, the basin is close to the maximum uplift zone of the central Southern Alps, with an estimated uplift rate of $12 \mathrm{~mm} \mathrm{a}^{-1}$ (Little et al. 2005).

Regional glacial chronology indicates that the Cropp Basin was filled with ice until about 16,000 cal BP (calibrated calendar years before 1950 AD; Gellatly et al. 1988). More recent dating of tills on the eastern side of the Southern Alps shows ice retreated after ca. 13,000 cal BP, following a late-glacial cooling during the Antarctic cold reversal between 14,900 and $12,900 \mathrm{cal} \mathrm{BP}$ (Kaplan et al. 2010). Till dated at 11,986 $\pm \mathrm{ca} .12,1000 \mathrm{cal} \mathrm{BP}$ from the middle reaches of the basin is interpreted as a subsequent late-glacial readvance (Basher and McSaveney 1989) and gives a maximum age for the postglacial surfaces. U-shaped cirques are present at the head of the Cropp River and its larger tributaries, but most of the glaciated landscape has been modified by postglacial fluvial and mass movement erosion. Slopes are steep $\left(30-60^{\circ}\right)$, valley profiles $\mathrm{v}$-shaped, and stream grades steep and uneven. Regolith is thin (generally $\leq 2 \mathrm{~m}$ ). A wide range of soils occurs, including yellow-brown earths, podzols, gley podozols, gley recent soils, gley soils and organic soils. Soils are generally shallow, strongly leached and infertile.

\section{Climate}

The western front ranges of the Southern Alps are characterised by frequent, heavy rainfall ( $>100 \mathrm{~mm} /$ day), annual precipitation in excess of $10,000 \mathrm{~mm}$ and persistent cloudiness. Mean annual rainfall of the Cropp Basin is estimated at $10,800 \mathrm{~mm} \mathrm{a}^{-1}$ (Griffiths and McSaveney 1983). Rainfall is usually well distributed throughout the year. Snow falls are frequent and may occur at any time during the year. Snow cover persists for about three months at treeline. Mean annual air temperature at Cropp Hut (865 m above sea level; 1982-1985; Tonkin and Basher 2001 ) is estimated at $5.5 \pm 0.5^{\circ} \mathrm{C}$, with a mean monthly range of $0-10.5^{\circ} \mathrm{C}$, and a mean annual soil temperature (at $0.5 \mathrm{~m}$ depth) of $6.0 \pm 0.5^{\circ} \mathrm{C}$. Mean daily temperature ranges from $15^{\circ} \mathrm{C}$ to $-5.5^{\circ} \mathrm{C}$, while the absolute range is from $23.4^{\circ} \mathrm{C}$ to $-10.1^{\circ} \mathrm{C}$. Frosts may occur at any time of the year but are most common and severe in June and July.

\section{Vegetation}

Land cover of the basin ranges from permanent snow and ice to dense montane forest, and the high, often torrential, rainfall promotes extensive landslides and soil erosion in the upper reaches. Vegetation descriptions of the valley follow Norton (1983) and our own observations (Basher 1986). Below $350 \mathrm{~m}$ to $400 \mathrm{~m}$ asl, dense, mixed conifer-angiosperm forests predominate, with tall conifers (Dacrydium cupressinum, Prumnopitys ferruginea and Podocarpus hallii) emergent over an angiosperm canopy dominated by Weinmannia racemosa. From $400 \mathrm{~m}$, the tall conifers gradually decline and Weinmannia racemosa and Metrosideros umbellata low forest extends up to $600 \mathrm{~m}$. A Metrosideros umbellata belt with emergent Libocedrus bidwillii continues to $800 \mathrm{~m}$, grading into a Libocedrus bidwillii forest without Metrosideros umbellata that interfingers with a low subalpine forest dominated by tall asterads (Olearia colensoi, O. ilicifolia, O. lacunosa,) and heaths (Archeria traversii, D. longifolium, Dracophyllum traversii) and other angiosperm small trees and shrubs (Coprosma pseudocuneata, Griselinia littoralis, Myrsine divaricata, Pseudopanax colensoi). Tall conical emergents of Libocedrus bidwillii and lower stature Podocarpus hallii, Phyllocladus alpinus and Halocarpus biformis occur in this association. This subalpine forest grades into alpine shrubland between $900 \mathrm{~m}$ and $1000 \mathrm{~m}$ asl, with a range of asterad and heath-dominated communities, Halocarpus biformis on old, leached soils, and Hoheria glabrata on young debris soils. Alpine grasslands replace shrubland at elevations between $900 \mathrm{~m}$ and $1400 \mathrm{~m}$ asl, depending on aspect, exposure and soil depth and age. Chionochloa spp. tussock grasses dominate well-drained sites, and species-rich communities of sedges, reeds, herbs and 
prostrate shrubs and cushion plants occur on poorly drained sites. These include the creeping podocarp Lepidothamnus laxifolium and low-growing Podocarpus nivalis.

There are numerous definitions of treeline in the literature but here we use the definition of Körner and Paulsen (2004): "the connecting line between the uppermost groups of upright trees of at least $3 \mathrm{~m}$ in height". By this criterion, treeline in Cropp Valley lies at about 1000 $\mathrm{m}$ asl. The regional treeline in this section of the western Southern Alps lies between $1200 \mathrm{~m}$ and $1150 \mathrm{~m}$, with annual average temperatures of $5.8-6.2^{\circ} \mathrm{C}$ (Ellen Cieraad pers. comm. 2011). The Cropp Valley treeline is therefore somewhat lower and colder than the regional treeline, probably because of cold-air drainage from the high reaches of the basin.

\section{Sites and methods}

Site locations are given in Figure 1, site stratigraphies in Figure 2, and radiocarbon date information in Table 1. All sites were sampled from exposed faces in pits or stream exposures.

Table 1. Sample locations and radiocarbon date details. Radiocarbon calibrations were calculated using the software CALIB v 5.0.1 (1) using the Southern Hemisphere Calibration dataset SHCal04 (2) (Stuiver and Reimer 1993; McCormac et al. 2004).

\begin{tabular}{|c|c|c|c|c|c|c|}
\hline Site & Grid ref. (NZMS1) & Material & $\begin{array}{l}\text { Cm below } \\
\text { surface }\end{array}$ & ${ }^{14} \mathrm{C}$ age BP & Cal BP (median) & $\begin{array}{l}{ }^{14} \text { C Lab } \\
\text { code }\end{array}$ \\
\hline \multirow{3}{*}{$\begin{array}{l}\text { Site 1. Cropp Hut: } \\
895 \mathrm{~m}\end{array}$} & \multirow[t]{3}{*}{ J34/439903 } & Peat & 25 & $1053 \pm 87$ & 908 & NZ6881 \\
\hline & & Peat & 55 & $2851 \pm 85$ & 2917 & NZ6878 \\
\hline & & Peat & $88-90$ & $7065 \pm 90$ & 7837 & NZ6115 \\
\hline \multirow{3}{*}{$\begin{array}{l}\text { Site 2. Tarkus Knob: } \\
950 \mathrm{~m}\end{array}$} & J34/444904 & Peat & 175 & $1748 \pm 38$ & 1600 & NZ5367 \\
\hline & \multirow[t]{2}{*}{ J34/441905 } & Peat & $160-162$ & $7381 \pm 70$ & 8134 & NZ5369 \\
\hline & & Peat & $170-180$ & $8390 \pm 76$ & 9337 & NZ5368 \\
\hline $\begin{array}{l}\text { Site 3. Steadman } \\
\text { Creek: } 820 \mathrm{~m}\end{array}$ & J34/446902 & Wood & See text & $10295 \pm 120$ & 12098 & NZ6576 \\
\hline
\end{tabular}

Site 1: Cropp Hut (field sample number: X8404)

A concave basin peat has formed in the distal zone of a prominent high-level alluvial cone of the north bank of Cropp River slightly upstream of the site of the former Cropp Hut (destroyed by a debris flow). The site has an elevation of $895 \mathrm{~m}$ and is on a forest-free subalpine valley floor. The plant communities of the general area are grassland (Chionochloa pallens and C. rubra) or grassland-low shrub on gently sloping surfaces, while steeply sloping surfaces are covered with subalpine scrub (Coprosma spp., Dracophyllum uniflorum, Olearia lacunosa, Phyllocladus alpinus, Podocarpus nivalis, Senecio bennettii) and forest (Archeria traversii, Dracophyllum longifolium, Libocedrus bidwillii, Halocarpus biformis). The peat surface is covered with Chionochloa rubra, Carpha alpina, Celmisia glandulosa, Donatia novae-zelandiae and Oreobolus pectinatus, and with substantial stands of the creeping podocarp, Lepidothamnus laxifolium. Ten samples were taken for pollen analysis and pollen results are given in Figures $3 \mathrm{a}$ and $\mathrm{b}$.

\section{Site 2: Tarkus Knob (field sample number X8207)}

Opposite the former Cropp Hut is a prominent ice-smoothed bedrock promontory informally named Tarkus Knob (elevation at site: $950 \mathrm{~m}$ ). A hollow along the northern margin of this feature has been in-filled by alluvium which contains two buried peat layers and is capped by a peaty soil. Three radiocarbon-dated samples for pollen analysis have been taken from two exposures along the hollow (Figure 2). The present vegetation is Chionochloa rubra grasslandcushion bog (Carpha alpina, Celmisia glandulosa, Donatia novae-zelandiae, Lepidothamnus 
laxifolium, Schoenus pauciflorus). Surrounding vegetation on well-drained slopes is as described for the Cropp Hut site.

Site 3: Terminal moraine, Steadman Creek (field sample X8512)

This site (grid reference NZMS2690 J34/446902; altitude $820 \mathrm{~m}$ ) is described in Basher and McSaveney (1989). A 30-40 m high terrace of the Cropp River consists of angular to sub-rounded boulders of schist, some with surface striations, in a sandy matrix. Decomposed twigs and logs (up to $20 \mathrm{~cm}$ in diameter) were found tightly embedded in a matrix of angular clasts towards the base of the section just above the bed of the river. A piece of wood was dated $(10,295 \pm 120 \mathrm{BP})$ and the matrix surrounding the wood sampled for pollen analysis.

Site 4: Surface sample sites (field samples X8621a, b and c)

Surface samples were taken from the surface of the Tarkus and Cropp Hut sites and are included as the upper levels in those pollen diagrams. A further surface sample was taken as far down the valley as could be reached on foot, at the confluence of the Cropp River and Reckless
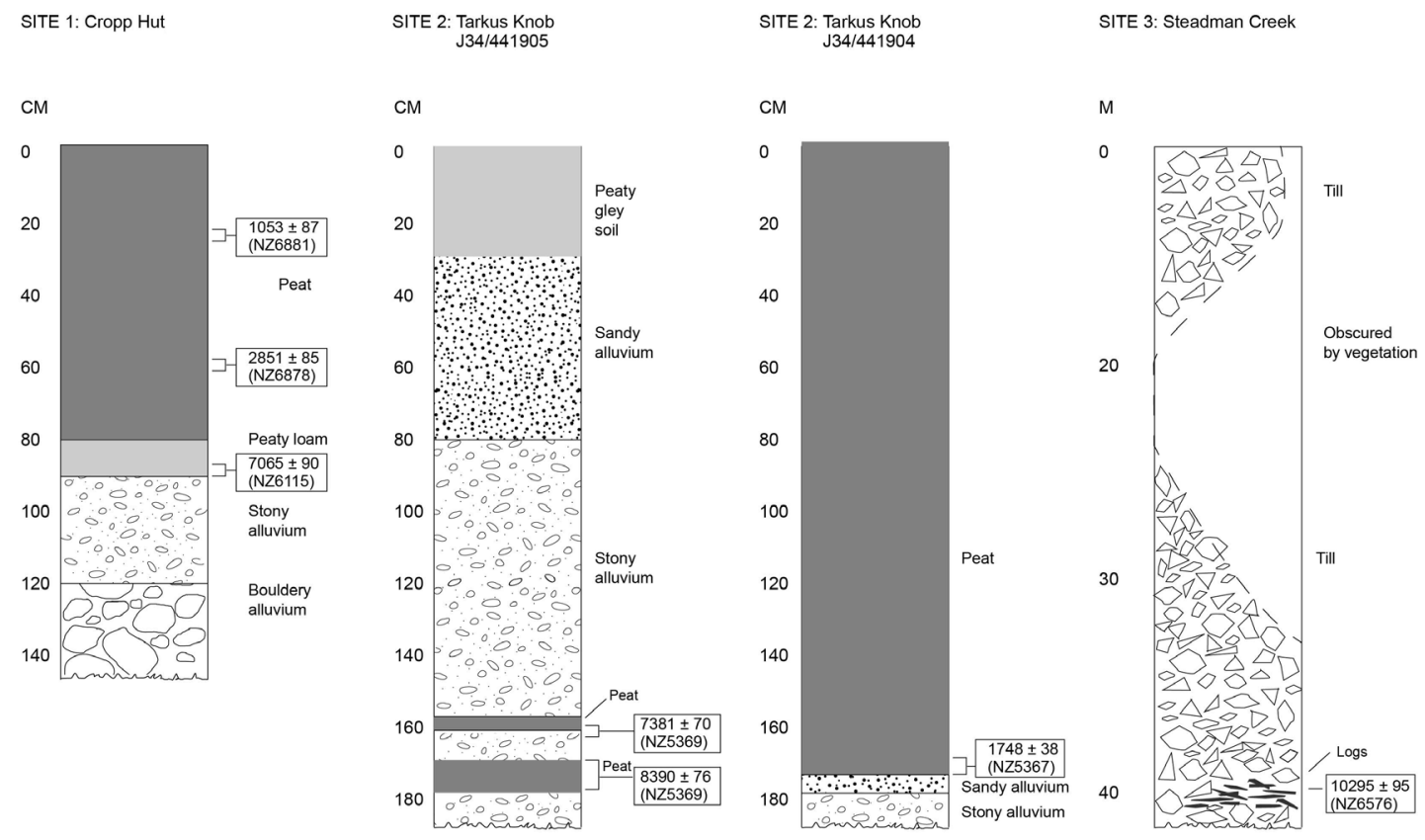

Figure 2. Site stratigraphies, Cropp Basin. Conventional radiocarbon ages in text boxes. The two Tarkus Knob exposures are less than $100 \mathrm{~m}$ apart. Note change of scale between Sites 1 and 2 and Site 3.

Torrent at an altitude of $820 \mathrm{~m}$. The site was a patch of wet Chionochloa rubra grassland within subalpine scrub approximately $1.5 \mathrm{~km}$ from tall montane forest.

Pollen and spore analysis followed standard extraction procedures (dehumification in 10\% $\mathrm{KOH}$, digestion in $40 \% \mathrm{HF}$, followed by acetolysis and mounting in glycerine jelly for light microscope examination). A terrestrial pollen sum of $>250$ grains was used and results are presented as a percentage of the terrestrial pollen sum.

\section{Results and discussion}

Modern pollen representation (see Figures 3 and 4)

Alpine and subalpine sites derive a large proportion of their pollen rain from wind- 
pollinated trees in lower altitude forests (Moar 1970; McGlone 1982; Pocknall 1982). The two uppermost sites sampled from subalpine grasslands derive ca. $35 \%$ of their pollen rain from lowland tree podocarps (Dacrycarpus dacrydioides, Dacrydium cupressinum, Prumnopitys ferruginea, P. taxifolia), whereas the lower surface sample site (Site 4, Reckless Torrent), in dense, low subalpine forest, derives only $21 \%$ of its pollen from that source. Metrosideros and Weinmannia, the primary canopy species of the high montane forest in the lower reaches of the basin, make up $<5 \%$ of the pollen rain. Although virtually absent from the upper altitude forests, two trees, Ascarina lucida and Quintinia serrata, and a liana, Ripogonum scandens, are also registered. Grass and subalpine scrub species (asterads, Coprosma, Dracophyllum, Halocarpus, Myrsine, Phyllocladus) average ca. 30\% for the two upper sites, but ca. 65\% for the lower. Although never making up a substantial proportion of the pollen rain, upland herbs, cushion plants and prostrate shrubs are represented. Although Libocedrus bidwillii is prominent in the upland low forest of the basin and wind-pollinated, it contributes surprisingly little to the pollen rain, averaging only ca. $1 \%$.

\section{Steadman Creek, till exposure (Figure 4)}

The Cropp till at $850 \mathrm{~m}$ is attributed to a late-glacial advance at ca. 12,100 cal BP, during which a glacier occupied most of the upper basin (Basher and McSaveney 1989). The wood was incorporated into the advance as the ice moved down valley. The pollen is derived from silt associated with the wood fragments and, as it was reworked by or deposited directly on the ice, is not directly comparable to that from the peat sequences. Exceptionally high levels of Hoheria (22\%) and abundant Coprosma, asterads and grass indicate an open low subalpine forest-shrubland, typical of what might be expected on disturbed sites within the basin at the present day. Hoheria glabrata currently does not extend more than about $200 \mathrm{~m}$ above the altitude of the till exposure and we conclude that subalpine low forest must have been close to its current limit during the advance. Nevertheless, a number of present-day components of the basin vegetation are missing from the pollen spectrum, including Dracophyllum, Halocarpus and Libocedrus, and lowland conifer forest trees make up only $6 \%$ of the pollen rain, rather than the 30\% average for the Holocene sites. Metrosideros and Weinmania are at trace levels only. Two broad conclusions can be made.

First, the Cropp glacier must have advanced down valley at a time when mean annual temperatures were close to those of the present. Hoheria glabrata forest does not extend higher than $1050 \mathrm{~m}$ in central Westland (Wardle 1991) and thus the maximum depression in mean annual temperature relative to the present can have only been of the order of $1.2^{\circ} \mathrm{C}$. However, as the wood was included within the till and not over-ridden, it is likely the Hoheria trees grew up-slope of the site. Given the steep gradient of the river, the Hoheria forest is likely to have grown at 900-1000 $\mathrm{m}$ altitude, that is, at its current limit.

The second conclusion is that the lowland to montane forest conifer emergents that provide more than $30 \%$ of the pollen rain at present must have been very much reduced in extent. This inference is supported by the pollen results from the extensive Okarito Pakihi mire at $70 \mathrm{~m}$ asl approximately $63 \mathrm{~km}$ to the southwest of the Cropp Basin (Newnham et al. 2007), where emergent conifers made up ca. $30 \%$ of the pollen rain at 12,000 cal BP, versus $95 \%$ during the Holocene. We therefore have the somewhat paradoxical results that woody vegetation was growing close to or at its present limit, while the upper limit to montane forest appears to have been lower and conifer forest in general much less abundant than now.

\section{Cropp Hut-Tarkus Knob peat sequences (Figures 3, 4 and 5)}

Cropp Hut and Tarkus Knob peats are in close proximity and both are currently in grassland vegetation, differing in altitude by $50 \mathrm{~m}$. Their pollen percentages at matched time intervals are 


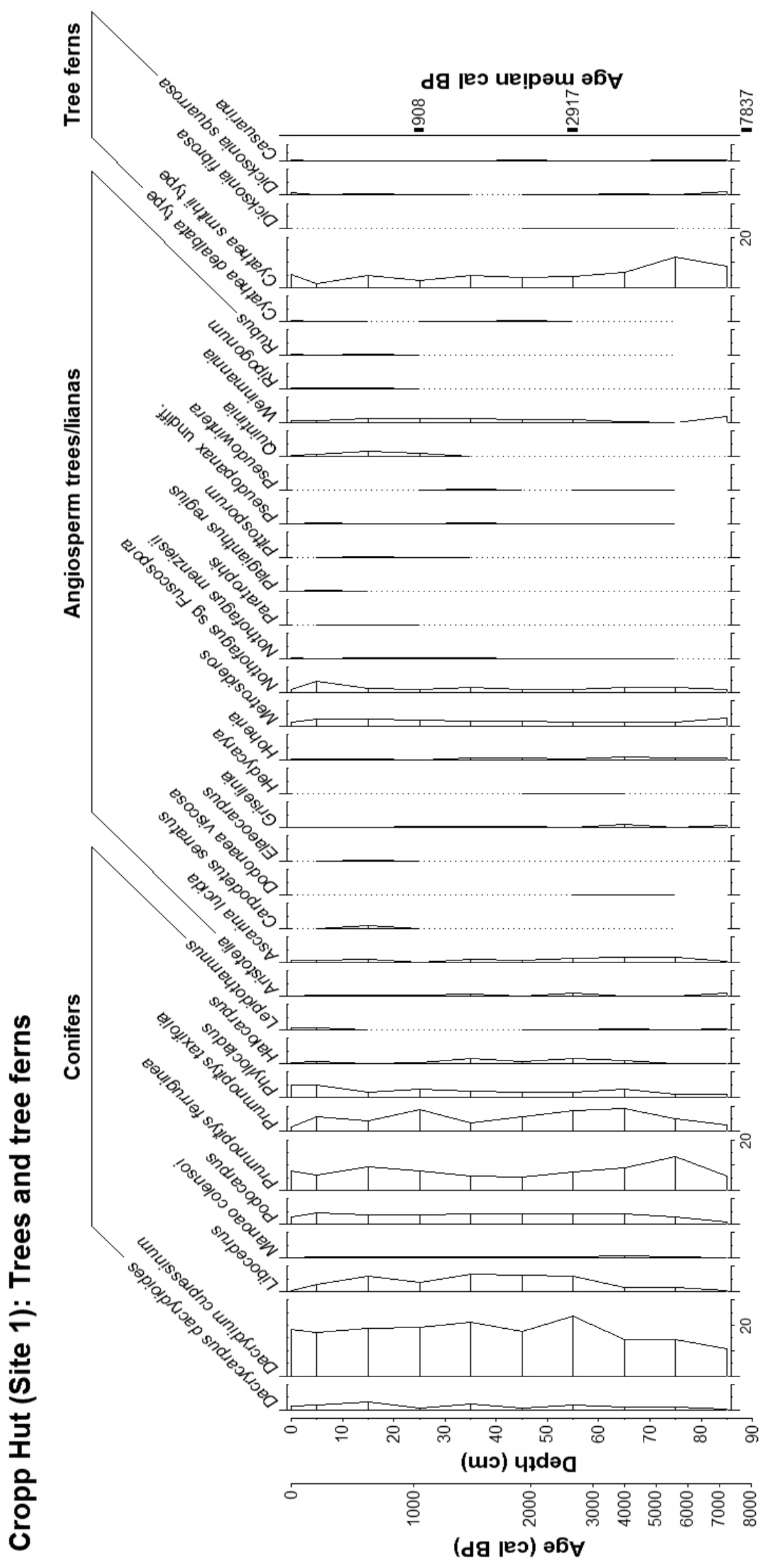




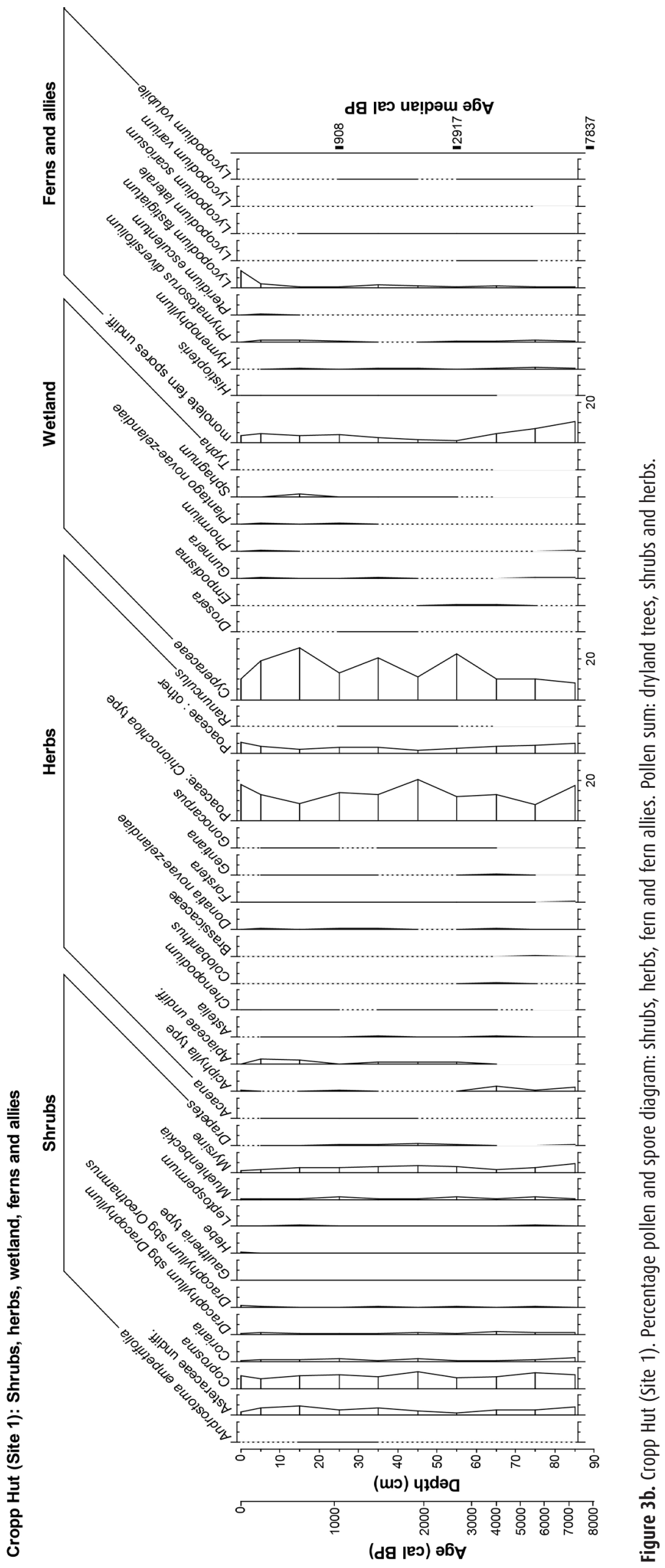




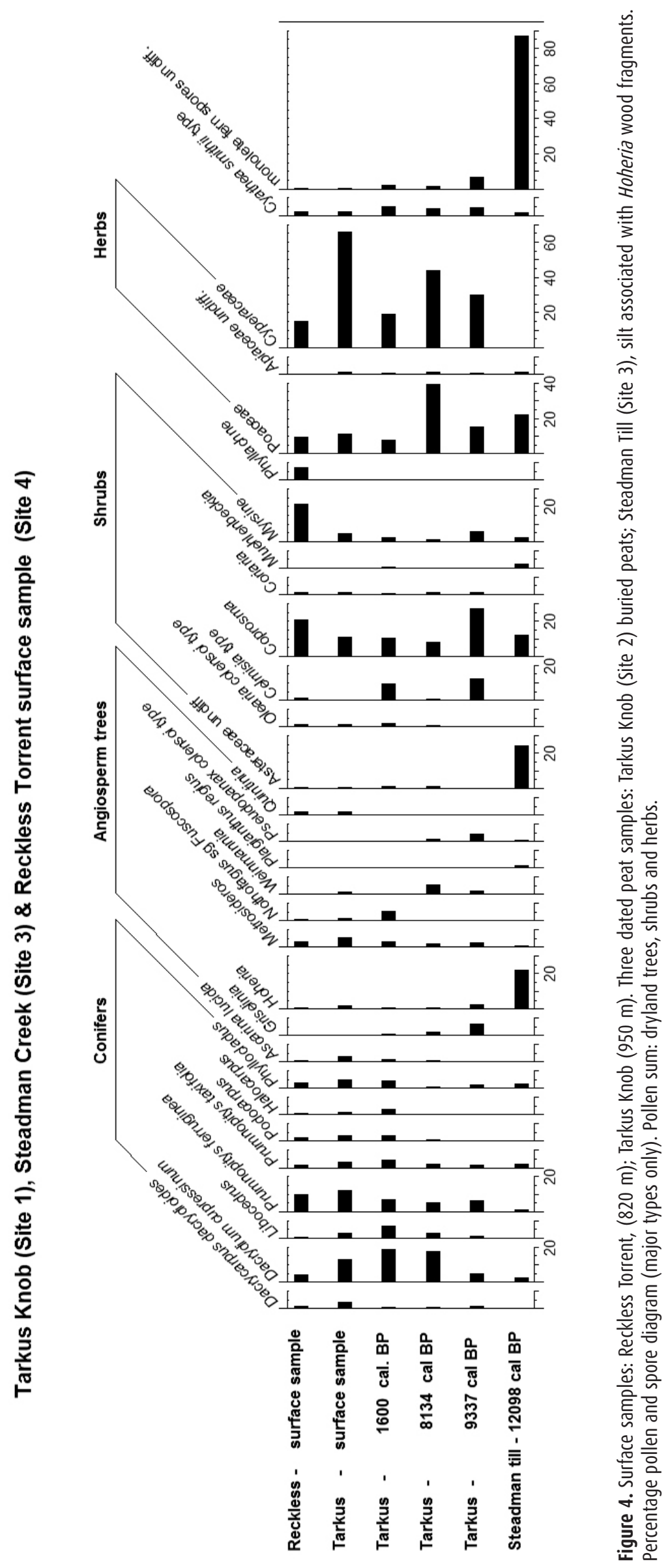


close, and they can be for most purposes treated as a single record. To get a generalised view of changes, a composite diagram for the arboreal pollen has been constructed from the Cropp Hut, Tarkus Knob and Steadman sequences (Figure 5).

Local vegetation cover appears to have been remarkably uniform throughout the Holocene. Grass pollen, dominated by Chionochloa, asterads, Coprosma Dracophyllum, Myrsine, and sedges and alpine herbs are consistently present at levels suggesting little or no change in the local vegetation structure from the current day (Figures 3 and 4).

The oldest sample (Tarkus Knob site; $9337 \mathrm{cal} \mathrm{BP}$ ) is ca. 2500 years younger than the till. Independent confirmation of the age of this sample is provided by the trace levels of Nothofagus versus the 1-5\% levels for those younger than 9000 cal BP. Nothofagus became the dominant forest cover between 8200 and $7500 \mathrm{cal} \mathrm{BP}$ in the Cass Basin, $70 \mathrm{~km}$ to the east (McGlone et al.2004), and this is the only likely source for this pollen type. The basal sample from the Cropp Hut peat section is younger than $8000 \mathrm{cal} \mathrm{BP}$ and has a significant Nothofagus representation.

The contribution of lowland conifer pollen rose from $13 \%$ to $20-25 \%$ by 7500 cal BP and reached present day levels of $30-40 \%$ by $6000 \mathrm{cal} \mathrm{BP}$ (Figure 5). High-altitude montane

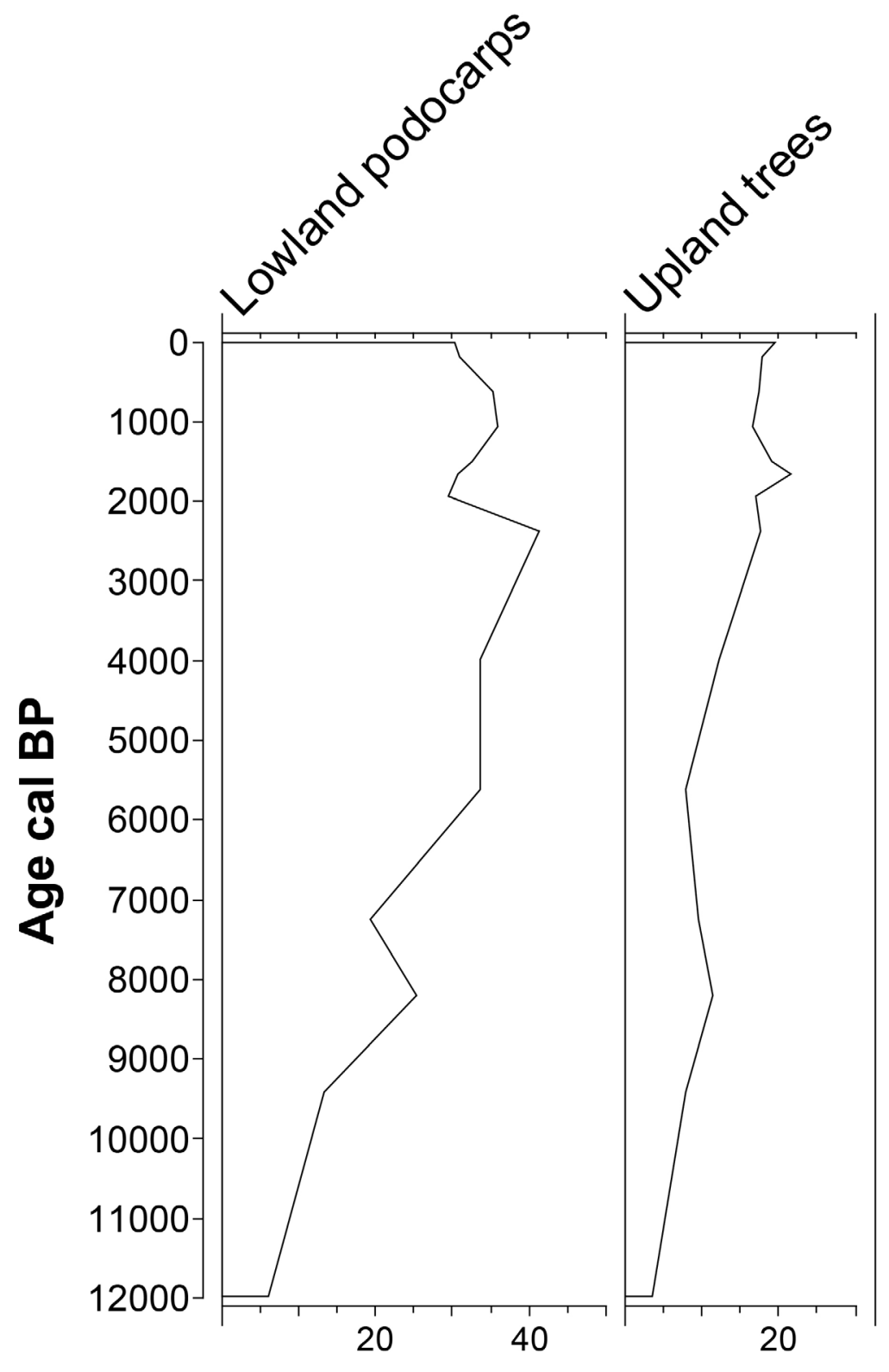

Figure 5. Summary composite percentage pollen diagram (Cropp, Tarkus, Steadman). Lowland pollen types: Dacrycarpus dacrydioides, Dacrydium cupressinum and Prumnopitys spp. Upland pollen types: Libocedrus, Phyllocladus, Podocarpus, Halocarpus, Metrosideros, Weinmannia and Quintinio. Note: lowland pollen types are those from emergent wind-pollinated trees that dominate the lowlands; the upland types are those that are known to occur either near the Cropp sites or in the upper montane forest (regardless of whether they also occur further downslope). 
forest types expanded from $8 \%$ to $12 \%$ between 9500 and 4000 cal BP, but did not reach current levels of $18 \%$ until $2400 \mathrm{cal} \mathrm{BP}$, which is when Libocedrus bidwillii became abundant within the basin. Tree-fern spores are dominated by Cyathea smithii type (which includes the short subalpine $C$. colensoi) at levels which suggest wind dispersal from montane forests but its percentage representation does not change in the course of the Holocene.

Quintinia is the last of the montane forest species to be registered at the site (between 1600 and $900 \mathrm{cal} \mathrm{BP}$ ). This canopy tree, characteristic of infertile soils in central Westland, is confined to scattered patches in the south of the district, and does not occur in south Westland. Wardle (1988) suggested that its distribution reflects a slow movement south from refugia in north Westland at the end of the last glaciation. However, it was present at Bell Hill, north Westland, before 10,400 cal BP (Moar 1971), but even there did not become abundant until ca. $3500 \mathrm{cal}$ BP (Pocknall 1980). A 7000-year migration lag for local spread seems improbable. It is far more likely that Quintinia was present throughout its current range at the end of the Last Glacial Maximum, as suggested by its trace occurrences then at Okarito Pakihi (Newnham et al. 2007), but remained uncommon until some aspect of the climate or soils became more favourable for the tree in the course of the late Holocene.

\section{Climate inferences}

As discussed in regard to Quintinia, there is no reason to suspect any of the dominant tree species were affected by migration lags: Weinmannia, Metrosideros, Quintinia and Libocedrus have small, wind-dispersed seeds and the podocarp trees have bird-dispersed fleshy fruits. While soil requirements may have been a constraint for some species, under the mild, highrainfall environment of Cropp Basin soils mature and become podozolized extraordinarily quickly, and landslides caused by heavy rain or earthquakes are a constant source of rejuvenated surfaces within the basin (Tonkin and Basher 2001). We therefore argue that the most probable explanation for the Holocene vegetation changes is the direct or indirect consequences of changing climate. Given that the Cropp Basin is directly in the path of the rain-bearing westerlies and has an enormous surplus of well-distributed precipitation far beyond the growth requirements of the vegetation, it further seems unlikely that changes in rainfall would have major effects on the vegetation cover. For that reason, we focus on changes in temperature and seasonality.

A marine-core alkenone sea-surface temperature record $200 \mathrm{~km}$ west of the Cropp Basin shows that temperatures peaked in the later late glacial, and were about $1.5^{\circ} \mathrm{C}$ warmer than present at 12,000 cal BP (Barrows et al. 2007). Pollen-based transfer functions show mean annual temperatures in South Island sites to have been warmer than now from about 12,000 cal BP (Wilmshurst et al.2007). The occurrence of tree-sized Hoheria glabrata high within the Cropp catchment at 12,000 cal BP, close to its upper limit, implies that temperatures during the growing season were within $1^{\circ} \mathrm{C}$ of those of the present. Warmer than present climates in the Cropp Basin by 12,000 cal BP therefore seem highly probable.

Nevertheless, some observations do not fit a scenario of summer temperatures at or above current values. In the cloudy, high-precipitation, mild climates of the western flank of the Southern Alps, winter cold is not a significant factor except in valley bottoms exposed to coldair drainage (Leathwick et al. 2003). It follows that regional alpine treelines are controlled by growing-season warmth, as demonstrated by Körner and Paulsen (2004). If summer temperatures were $1.5^{\circ} \mathrm{C}$ warmer than now, vegetation zones should have been some $250 \mathrm{~m}$ higher and the upper limit to closed montane forest at ca. 850-1000 m asl. Forest would have surrounded the Cropp sites. The absence of montane forest trees, and conifers in particular, from the catchment in the early Holocene demonstrates this did not happen. New Zealand glaciers in the central Southern Alps are much more responsive to summer ablation than 
winter precipitation (Anderson and Mackintosh 2006). The fact that a glacier advanced beyond Holocene limits to fill the upper Cropp Valley and produce the Cropp till is therefore also incompatible with summer temperatures warmer than those of the present.

Cool summers but higher than present mean annual temperatures necessarily imply much warmer and shorter winters. In temperate latitudes, warm winters are important in the lowlands as they permit frost-sensitive species to flourish. In contrast, at treeline, warm winters are largely irrelevant or even detrimental, as warm temperatures may break dormancy and increase frost. Cool summers and warm winters create an intensely oceanic environment which is understood to further limit tree growth through restricting photosynthesis in summer and increasing metabolic energy expenditure in winter (Stevens and Fox 1991; Crawford 2000). Tall podocarps were less common than now during this intensely oceanic phase in the nearby lowlands at Okarito (Newnham et al. 2007) and it is possible that they were also restricted by cool summers. We conclude that in the late glacial and early Holocene, a warm-winter/ cool-summer regime depressed altitudinal forest zones and may have had a disproportionate influence on tall conifer trees.

The Holocene vegetation sequence within the Cropp Valley (Figure 5) is best interpreted as a response to steady increases in summer temperature. By $8200 \mathrm{cal} \mathrm{BP}$, upper montane forests were present in the lower reaches of the valley. By $2500 \mathrm{cal}$ BP, Libocedrus bidwillii had occupied the upper part of valley, and lowland-forest pollen rain peaked about the same time, suggesting that upslope movement of forest zones had not reached current altitudes until then.

Other New Zealand sites near treeline or in montane settings support the scenario that summer temperatures have been rising in the course of the Holocene. Pollen and macrofossil evidence from subantarctic Auckland and Campbell Islands indicates that forest did not reach current extent until $6000 \mathrm{cal} \mathrm{BP}$, and may have continued to extend upslope into the late Holocene (McGlone 2002; McGlone et al. 2010). In the Garvie Mountains (Central Otago), high-altitude grassland was abruptly replaced by coniferous forest at $8300 \mathrm{cal} \mathrm{BP}$ (McGlone et al. 1995). Pollen sites close to treeline in northwest Nelson suggest late-Holocene spread of subalpine Nothofagus forest into low woody vegetation and grassland (Shulmeister et al. 2003). In the North Island, in an altitudinal sequence of organic soil pollen sites across treeline (1140$1470 \mathrm{~m}$ asl) on the isolated massif of Mount Hauhungatahi, Tongariro, low conifer forest rose to dominance at ca. $9700 \mathrm{cal} \mathrm{BP}$, but the current tall Nothofagus-Libocedrus forest spread only from ca. $8000 \mathrm{cal} \mathrm{BP}$, and was not dominant until several thousand years later (Horrocks and Ogden 2000).

A forest ecosystem process model has been used in inverse mode to explore early Holocene climate scenarios based on pollen and macrofossil data from Cass, an intermontane site 70 $\mathrm{km}$ east of the Cropp Valley at $600 \mathrm{~m}$ altitude (McGlone et al. 2011). Best fit between early Holocene vegetation and climate was obtained when summers were no warmer than present but winters substantially warmer. If early Holocene summers were set at $0.5^{\circ} \mathrm{C}$ cooler than present, and compensated for by much warmer winters to achieve an overall warmer climate $\left(+1.5^{\circ} \mathrm{C}\right)$, suitable matches could also be made. Annual ocean-surface warmth and terrestrial summer cooling in the early Holocene can thus be reconciled.

The mountain ranges of Tasmania and the southeastern coast between $43^{\circ} \mathrm{S}$ and $30^{\circ} \mathrm{S}$ provide the closest comparable sites in Australia to Cropp Valley. Changes in Australian upland regions are complicated by major alterations in rainfall patterns which result in asynchronous vegetation change between sites (Donders et al. 2007). Nevertheless, there is agreement that summer temperatures and forest cover peaked in the mid Holocene, as early recognised by Kershaw (1988). At the northern edge of the temperate forest zone in New South Wales, at high-altitude (1200-1500 m asl) sites on Barrington Top, current forest was established by $10,000 \mathrm{cal} \mathrm{BP}$ and vegetation typical of warmer and moister conditions was widespread over 
the plateau between 7500 and 4000 years ago (Dodson et al. 1986). In Kosciuszko National Park in New South Wales, sites at treeline had grassy alpine herbfields until ca. 12,500 cal BP and Eucalyptus increased to form similar communities to those at current treeline by 7500 cal BP. Subalpine woody communities reached maximum development between 6000 and 3000 cal BP (Martin 1986, 1999). It is possible that drier conditions earlier in the Holocene may have delayed this maximum. In south-central Victoria, forest reached current levels at several high-altitude sites after 11,500 cal BP (McKenzie 1997,2002; Kershaw et al. 2007), but wet Eucalpytus forests and Nothofagus did not achieve maximum extent until ca. $7000 \mathrm{cal} \mathrm{BP}$ (McKenzie 2002). Changes after ca. $4500 \mathrm{cal} \mathrm{BP}$ are complicated by the onset of ENSO and changing precipitation, but the decline in moisture-loving Nothofagus may have resulted from the transpiration stress of increasing summer temperatures. In Tasmania, maximum treeline altitude and warmest growing-season temperatures appear to have been achieved by $7000 \mathrm{cal}$ BP (Anker et al. 2001; Fletcher and Thomas 2007).

In summary, Australian results are consistent with those from the Cropp Valley in that they show treelines were lower than now before $11,500 \mathrm{cal} \mathrm{BP}$ and current treelines mostly formed only after 7000 cal BP.

Schaefer et al. (2009) note that Holocene glacier advances in the central Southern Alps of New Zealand diminish in volume towards the present. They suggest this is largely due to increased summer ablation, consistent with our claim that treelines have risen and summers warmed in the course of the Holocene. It follows then that ocean-surface temperatures, which fall during the mid-to-late Holocene as treelines rise (Barrows et al. 2007), must reflect substantial winter cooling.

\section{Conclusions}

The latter part of the late glacial and early Holocene in New Zealand was characterised by low treelines relative to the present. In the upper Cropp Valley, although shrubs and small trees extended up to current treeline, the current montane-alpine forest was absent, including the conifer Libocedrus. Similar patterns of change are seen at near-treeline sites throughout New Zealand, usually involving the late spread of Nothofagus forest into early Holocene tall shrubland. We conclude that highly oceanic environments during the late glacial-early Holocene period, characterised by warm winters and cool summers, disproportionately affected trees in the montane to alpine zones. There is a great deal of similarity in timing between the New Zealand montane-alpine vegetation sequences over the late glacial and Holocene, and those of the mountainous areas of Tasmania and southeastern Australia. This probably reflects a common response to a hemispheric temperature trend. Although increasing precipitation after a drier early Holocene is often suggested as a contributory factor to changing treelines at Australian sites, this is far less likely to have been an issue at New Zealand alpine sites.

We suggest that during the latter half of the late glacial and the early Holocene, cool summers, warm winters and generally drier than present conditions prevailed in southeastern Australia and New Zealand. Summers shortened but became warmer, while winters lengthened and cooled in the course of the Holocene. As a consequence, apparently contradictory trends emerged in the mid-to-late Holocene: lowland forests changed character, losing frost-sensitive components as winters became cooler, while alpine trees began to replace previous lowgrowing shrublands in response to warmer summers. The decline from peak summer warmth in montane-alpine regions noted in Australia after $5000-4000 \mathrm{cal} \mathrm{BP}$ is not as obvious in New Zealand records. 


\section{Acknowledgements}

We thank Neville Moar and Janet Wilmshurst for their comments on a draft of the manuscript, and Rewi Newnham and Geoffrey Hope for their reviews. MSM would also like to record his gratitude to Peter Kershaw for his encouragement and support over many years.

\section{References}

Anderson, B. and Mackintosh, A. 2006. Temperature change is the major driver of late-glacial and Holocene glacier fluctuations in New Zealand. Geology 34:21-124.

Anker, S.A., Colhoun, E.A., Barton, C.E., Peterson, M. and Barbetti, M. 2001. Holocene vegetation and paleoclimatic and paleomagnetic history from Lake Johnston, Tasmania. Quaternary Research 56:264-274.

Barrows, T.T., Lehman, S.J., Fifield, L.K. and De Deckker, P. 2007. Absence of cooling in New Zealand and the adjacent ocean during the Younger Dryas Chronozone. Science 318:8689.

Basher, L.R. 1986. Pedogenesis and erosion history in a high rainfall, mountainous drainage basin - Cropp River, New Zealand. Unpublished doctoral thesis, Department of Soil Science. Lincoln College, University of Canterbury.

Basher, L.R. and McSaveney, M.J. 1989. An early Aranuian glacial advance at Cropp River, central Westland, New Zealand. Journal of the Royal Society of Nerw Zealand 19:263-268.

Crawford, R.M.M.2000. Ecological hazards of oceanic environments. Nerw Phytologist 147:257281.

Cullen, L.E., Stewart, G.H., Duncan, R.P. and Palmer, J.G. 2001. Disturbance and climate warming influences on New Zealand Nothofagus tree-line population dynamics. Journal of Ecology 89:1061-1071.

Dodson, J.R., Greenwood, P.W. and Jones, R.L.1986. Holocene Forest and Wetland Vegetation Dynamics at Barrington Tops, New South Wales. Journal of Biogeography 13:561-585.

Donders, T.H., Haberle, S.G., Hope, G., Wagner, F. and Visscher, H. 2007. Pollen evidence for the transition of the eastern Australian climate system from the post-glacial to the presentday ENSO mode. Quaternary Science Reviews 26:1621-1637.

Fletcher, M.S. and Thomas, I. 2007. Holocene vegetation and climate change from near Lake Pedder, south-west Tasmania, Australia. Journal of Biogeography 34:665-677.

Gellatly, A.F., Chinn, T.J.H. and Röthlisberger, F. 1988. Holocene glacier variations in New Zealand - a review. Quaternary Science Reviews 7:227-242.

Griffiths, G.A. and McSaveney, M.J.1983. Hydrology of a basin with extreme rainfalls - Cropp River, New Zealand. Nerw Zealand Journal of Science 26:293-306.

Harsch, M.A., Hulme, P.E., McGlone, M.S. and Duncan, R.P. 2009. Are treelines advancing? A global meta-analysis of treeline response to climate warming. Ecology Letters 12:10401049.

Horrocks, M. and Ogden,J. 2000. Evidence for Lateglacial and Holocene tree-line fluctuations from pollen diagrams from the Subalpine zone on Mt Hauhungatahi, Tongariro National Park, New Zealand. Holocene 10:61-73.

Kaplan, M.R., Schaefer, J.M., Denton, G.H., Barrell, D.J.A., Chinn, T.J.H., Putnam, A.E., Andersen, B.G., Finkel, R.C., Schwartz, R. and Doughty, A.M. 2010. Glacier retreat in New Zealand during the Younger Dryas stadial. Nature 467:194-197.

Kershaw, A.P. 1988. Australasia. In: Huntley, B. and Webb 11l, T. (eds), Vegetation History, pp. 237-306. Dordrecht: Kluwer Academic Publishers.

Kershaw, A.P., McKenzie, G.M., Porch, N., Roberts, R.G., Brown, J., Heijnis, H., Orr, M.L., 
Jacobsen, G. and Newallt, P.R. 2007. A high-resolution record of vegetation and climate through the last glacial cycle from Caledonia Fen, southeastern highlands of Australia. Journal of Quaternary Science 22:481-500.

Kershaw,A.P.and Strickland,K.M.1988. The development of alpine vegetation on the Australian mainland. In: Good, R. (ed), The Scientific Significance of the Australian Alps: the proceedings of the first Fenner Conference on the Environment, pp. 113-125. Canberra: Australian Alps National Parks Liaison Committee and the Australian Academy of Science.

Körner, C. and Paulsen, J. 2004. A world-wide study of high altitude treeline temperatures. Journal of Biogeography 31:713-732.

Leathwick, J.R., Wilson, G., Rutledge, D., Wardle, P., Morgan, F., Johnston, K., McLeod, M. and Kirkpatrick, R. 2003. Land Environments of Nerw Zealand. Auckland: David Bateman.

Little, T.A., Cox, S., Vry, J.K. and Batt, G. 2005. Variations in exhumation level and uplift rate along the oblique-slip Alpine fault, central Southern Alps, New Zealand. Geological Society of America Bulletin 5-6:707-723.

Martin, A.R.H. 1986. Late Glacial and Holocene alpine pollen diagrams from the Kosciusko National Park, New South Wales, Australia. Review of Palaeobotany and Palynology 47:367409.

Martin, A.R.H. 1999. Pollen analysis of Digger's Creek Bog, Kosciuszko National Park: Vegetation history and tree-line change. Australian Journal of Botany 47:725-744.

McCormac, F.G., Hogg, A.G., Blackwell, P.G., Buck, C.E., Higham, T.F.G. and Reimer, P.J. 2004. SHCal04 Southern Hemisphere calibration, 0-11.0 cal kyr BP. Radiocarbon 46:10871092.

McGlone, M.S. 1982. Modern pollen rain, Egmont National Park, New Zealand. New Zealand Journal of Botany 20:253-262.

McGlone, M.S. 1988. New Zealand. In: Huntley, B. and Webb III, T. (eds), Vegetation History, pp. 557-599. Dordrecht: Kluwer Academic Publishers.

McGlone, M.S. 2002. The late Quaternary peat, vegetation and climate history of the southern oceanic islands of New Zealand. Quaternary Science Reviews 21:683-707.

McGlone, M.S., Hall, G.M.J. and Wilmshurst, J.M. 2011. Seasonality in the early Holocene: Extending fossil-based estimates with a forest ecosystem process model. The Holocene 21:517-526.

McGlone, M.S., Mark, A.F. and Bell, D. 1995. Late Pleistocene and Holocene vegetation history, central Otago, South Island, New Zealand. Journal of the Royal Society of New Zealand 25:1-22.

McGlone, M.S., Mildenhall, D.C. and Pole, M.S. 1996. History and palaeoecology of New Zealand Nothofagus forests. In: Veblen, T.T., Hill, R.S. and Read, J. (eds), The Ecology and Biogeography of Nothofagus forest, pp. 83-130. New Haven: Yale University Press.

McGlone, M.S., Turney, C.S.M. and Wilmshurst, J.M. 2004. Late-glacial and Holocene vegetation and climatic history of the Cass Basin, central South Island, New Zealand. Quaternary Research 62:267-279.

McGlone,M.S., Turney, C.S.M.,Wilmshurst,J.M., Renwick,J. and Pahnke, K. 2010. Divergent land and ocean temperature trends in the Southern Ocean over the past 18,000 years. Nature Geoscience 3:622-626.

McKenzie, G.M. 1997. The late Quaternary vegetation history of the south-central highlands of Victoria, Australia. 1. Sites above 900 m. Australian Journal of Ecology 22:19-36.

McKenzie, G.M. 2002. The late Quaternary vegetation history of the south-central highlands of Victoria, Australia. II. Sites below 900 m. Austral Ecology 27:32-54.

Moar, N.T. 1970. Recent pollen spectra from three localities in the South Island, New Zealand New Zealand Journal of Botany 8:210-221. 
Moar, N.T. 1971. Contributions to the Quaternary history of the New Zealand flora. 6. Aranuian pollen diagrams from Canterbury, Nelson, and north Westland, South Island. New Zealand Journal of Botany 9:80-145.

Newnham, R.M., Vandergoes, M.J., Hendy, C.H., Lowe, D.J. and Preusser, F.2007. A terrestrial palynological record for the last two glacial cycles from southwestern New Zealand. Quaternary Science Reviews 26:517-535.

Norton, D.A. 1983. Population dynamics of subalpine Libocedrus bidwillii forests in the Cropp River Valley, Westland, New Zealand. Nerw Zealand Journal of Botany 21:127-134.

Pocknall, D.T. 1980. Modern pollen rain and Aranuian vegetation from Lady Lake, North Westland, New Zealand. New Zealand Journal of Botany 18:275-284.

Pocknall, D.T. 1982. Modern pollen spectra from mountain localities, South Island, New Zealand. New Zealand Journal of Botany 20:361-371.

Schaefer,J.M, Denton, G.H., Kaplan, M., Putnam, A., Finkel, R.C., Barrell, D.J.A., Andersen, B.G., Schwartz, R., Mackintosh, A., Chinn, T. and Schluchter, C. 2009. High-Frequency Holocene Glacier Fluctuations in New Zealand Differ from the Northern Signature. Science 324:622-625.

Shulmeister, J., McLea, W.L., Singer, C., McKay, R.M. and Hosie, C. 2003. Late Quaternary pollen records from the Lower Cobb Valley and adjacent areas, North-West Nelson, New Zealand. New Zealand Journal of Botany 41:503-533.

Stevens, G.C. and Fox,J.F.1991. The causes of tree line.Annual Review of Ecology and Systematics 22:177-191.

Stuiver, M.P. and Reimer, P.J. 1993. Extended 14C data base and revised CALIB 3.0 14C age calibration program. Radiocarbon 35:215-230.

Tonkin, P.J. and Basher, L.R. 2001. Soil chronosequences in subalpine superhumid Cropp Basin, western Southern Alps, New Zealand. New Zealand Journal of Geology and Geophysics 44:37-45.

Wardle, P. 1985a. New Zealand timberlines. 3. A synthesis. New Zealand Journal of Botany 23:263-271.

Wardle, P. 1985b. New Zealand timberlines. 1. Growth and survival of native and introduced tree species in the Craigieburn Range, Canterbury. New Zealand Journal of Botany 23:219234.

Wardle, P. 1988. Effects of glacial climates on floristic distribution in New Zealand. 1. A review of the evidence. New Zealand Journal of Botany 26:541-555.

Wardle, P. 1991. Vegetation of New Zealand. Cambridge: Cambridge University Press.

Wardle, P. 2008. New Zealand forest to alpine transitions in global context. Arctic Antarctic and Alpine Research 40:240-249.

Wardle, P. and Coleman, M.C. 1992. Evidence for rising upper limits of 4 native New Zealand forest trees. New Zealand Journal of Botany 30:303-314.

Wilmshurst, J.M., McGlone, M.S., Leathwick, J.R. and Newnham, R.M. 2007. A predeforestation pollen-climate calibration model for New Zealand and quantitative temperature reconstructions for the past 18000 years BP. Journal of Quaternary Science 22:535-547. 